\title{
The Right to Culture in Performance-Driven American Public Schools -Some Implications of United States Ratification of the International Covenant on Civil and Political Rights and the Convention on Elimination of All Forms of Racial Discrimination
}

\author{
Rosemary Ann Blanchard, Ph.D. \\ Associate Professor of Education, California State Unviersity, Sacramento
}

\begin{abstract}
The right of ethnic, linguistic and indigenous minorities to an education for their children that supports their linguistic identity and cultural continuity is a universally-recognized human right throughout the world community. The United States, while a signatory to the main international agreements which establish this right has yet to adequately domesticate its interpretation and implementation. Educators and policy makers at every level of government and society have both the ethical responsibility and the opportunity to incorporate the fundamental elements of the human right to culture into their educational planning, program development, instruction and assessments. As Justice Black noted more than 50 years ago, "Great nations, like great men [and women] should keep their word..
\end{abstract}

Critics of American education frequently draw comparisons with the educational outcomes achieved by countries as diverse as Finland and the Republic of Singapore (Sclafani, 2008). The virtues of high levels of conformity within strongly centralized national programs are compared and contrasted with the virtues of high levels of autonomy within decentralized and localized systems. Yet in the many comparative studies and dire warnings that American schools and American students are falling behind their global peers and competitors, rarely if ever is any fuss made about one area where education in the United States has long been drifting away from standards recognized throughout the global village. This area derives from universally recognized standards of human rights, acknowledged in international declarations and ratified (even by the United States) in treaties: the right of racial, ethnic and linguistic minorities and indigenous peoples, both individually and in community with their group to equitable access to the resources necessary to protect, preserve and develop their cultures. Of particular interest to this researcher is the well established and growing body of international human rights opinion regarding the place of culturally and linguistically appropriate education in protecting the civil, human and cultural rights of racial, ethnic and linguistic and indigenous minorities within the nation states where they reside.

The United States' embrace of its diverse "huddled masses" has had an ambivalent quality to it since the days of John Dewey and even earlier. On the one hand, those masses have been invited into the American melting pot. On the other hand, they have not really been accorded the right to choose the place of their home culture, language and ways of knowing in the educational induction of their children (Strouse, 1987). 
In contemporary discourse about educational reform, a centripetal drive toward unitary academic identifiers, common standards and curricula often overshadows the centrifugal pull of commitments to protect racial, ethnic and cultural diversity. The contemporary tendency to measure educational achievement through recorded scores on monocultural tests of easily measurable academic skills continues and even exaggerates this tendency (Burdick-Will \& Gomez, 2006). The absence of any meaningful discussion of the cultural rights of racial, ethnic, linguistic and indigenous minorities from the educational reform debates is troubling and constitutes a weakness in both the inclusivity and the rigor of the educational reform movement.

The central thesis of this paper is that the right to culture of racial, ethnic, linguistic and indigenous minorities must be explicitly considered and protected in every instance where decisions are being made about publicly funded education. The United States government has lent its name to international human rights declarations and has given its solemn word through the ratification of international treaties that the right to culture will be respected at every appropriate level of government (U.S. Senate, Executive Calendar 17, April 2, 1992). This paper also acknowledges that consideration of the human right to culture is generally absent from contemporary debates about public education . A "decent respect to the opinions of [hu]mankind" (U.S. Declaration of Independence, paragraph 1, 1776) should persuade educators committed to transformative practice to correct this omission and begin building best practices for supporting cultural and linguistic diversity into their educational models.

\section{Domestic and International Perspectives on Improving Education for Minority Students}

Research on teaching and learning in the later 20th and early 21st Centuries has opened exciting possibilities for creative innovations on the content and delivery of education in American schools. (Sleeter, 1995; Chaiklin \& Lave 1993; Gagne, Yekovich, \& Yekovich 1993). Education practitioners and researchers know more than ever before about how to adapt school-based education to students' cultural and linguistic backgrounds, learning styles and developmental configurations (New Mexico Public Education Department, 2007). Equality of educational opportunity has been the law for more than 30 years (20 USC. §1221-I, 1703, et seq.).

At the same time, authentic equality of educational opportunity for ethnic, linguistic and Indigenous minorities, including equality of voice in determining goals, methods, and legitimizing criteria for public education, is not progressing apace with our growing expertise. There are many reasons for this disconnect between what we as educators know and the outcomes of publicly funded education. Some are overtly political. Frontal attacks on bilingual/bicultural education and the "English only" movement with their attendant calls for "cultural literacy" seek to establish the AngloEuropean world view as the only legitimate educational perspective in American schools and the American English language as the only legitimate language of instruction (Bloom 1987; Cheney 1995;. Hirsch 1987).

However, a serious threat/impediment to authentic multicultural/multiethnic education resides in the heart of systemic reform. As the world makes a continuing transition to post-industrial technology, and American demographics shift from a population with a Northern European majority to a population with no single center of origination, it stands to reason that the purposes, methods and outcomes of educational institutions should be revisited and that the entire enterprise should undergo a re-visioning. Likewise, because the issues are so important, it is not surprising that they are debated in an environment that is as political as it is pedagogical. Today's multicultural educators dare not abandon the realm of law and politics for the high ground of curriculum and cognition studies only. Indeed, the tools employed in policy making and policy analysis are tools of cultural survival. Recent decisions by the U.S. Supreme Court have made clear that neither the lingering effects of past discrimination nor the positive benefits of school diversity will be allowed to justify affirmative steps to address issues of inequality among racial and ethnic groups (Parents Involved in Community Schools v. Seattle School District, 2007). However, debates about affirmative action even in its heyday often failed to adequately address issues concerning locus of authority for curricular and pedagogical decision making. Access to the existing 
educational resources of society on an affirmative action basis still stopped short of access to the decision making processes regarding the content, methods and purposes of those resources (Charleston, 1994; Shapiro, Sewell \&DuCette 1992).

As an example, No Child Left Behind, like previous systemic educational reform efforts, has sought to reward good teaching (Yell, Drasgow \& Drasgow, 2005). The Obama administration's implementation of NCLB, the Education provisions of the American Recovery and Reinvestment Act of 2009 (ARRA, Division A, Section 14006, Public Law 111-5), and the much vaunted Race to the Top are even more focused on rewarding "good teaching" and defining the measures of education effectiveness (see http://www.ed.gov/policy/gen/ leg/recovery/index.html and linked sites, retrieved 09/30/2009). Fuhrman, Clune and Elmore (1988) noted that rewarding good teaching requires "consensus on key values, like what constitutes 'good' teaching" (p. 214). Multicultural educators and minority ethnic, indigenous and linguistic communities have a right which is too often overlooked to play a key role in determining what constitutes "good teaching" of their own children. This includes not only participating in the determination of methods and alignment of teaching styles with learning styles, but also a determination of the core standards which will drive the whole endeavor. Strategies adopted in a school to increase academic mastery through methods that undermine students' cultural and linguistic competence in their own linguistic and ethnic group need to be recognized as evidence of "bad teaching" no matter what the standardized tests say (Charleston, 1994).

This interpretation of "good teaching" and "bad teaching" may appear to be wishful thinking, given the radical changes No Child Left Behind brought to the education of students whose first language is not English. After all, Title III of NCLB essentially eliminates the term "Bilingual Education," ends competitive grants to individual schools and establishes the only recognized goal of the new title as English language acquisition. The descriptors of the core elements upon which Race to the Top competitive grant applications will be evaluated by the U.S. Department of Education, while rigorous, focus on a unitary vision of educational competence. Likewise, the movement toward national standards or common core standards agreed to by all of the states, while admirable on many levels, also does not appear to provide any space for attending to the cultural rights of diverse students. The "Top," to which American education is racing, is rarely described in terms of multicultural, multilingual, multi-cognitive outcomes.

Nonetheless, viewed through a global lens, the more holistic understanding of the appropriate relationship between public education and home cultures of ethnic, linguistic and indigenous minorities advocated in this paper has been a widely accepted world standard for more than a quarter century (Capotorti 1979; Martinez Cobo 1987; UN Commission on Human Rights Report of the Expert Mechanism on the Rights of Indigenous Peoples, 2009). The binary which so often affects educational planning in the United States too often equates rigorous educational reform with unitary goals and measures of educational accomplishment. Yet the measure of nondiscriminatory education presented in the expert assessments of international rapporteurs, jurists and commissioners interpreting the clear meaning of treaties which the United States itself has ratified is in every case holistic - according priority both to educational rigor by national and international standards and cultural congruence with the home cultures of indigenous peoples and racial, ethnic and linguistic minorities Consider, for example, the Concluding Observations of the Committee on Elimination of Racial Discrimination, $\S 38$ (2008) and the Report of the Expert Mechanism on the Rights of Indigenous Peoples, \$21 (2009) for evidence of this assertion.

Americans often demonstrate a marked provincialism, compared to the rest of the world community, in analyzing and addressing issues like the status of ethnic, linguistic and indigenous minorities within the institutions of the dominant society, including the institution of education. Even American ethnic, linguistic and indigenous minority advocates often neglect to incorporate international human rights standards into their advocacy. This lack of domestic awareness of the domestic implications of the international commitments which the United States has made is frequently commented upon by international commissions in which the United States 
participates and to which it presents annual overviews (See for example, CERD questions to the United States 2008, § 32; CERD Concluding Remarks in 2008, § 36). It has been acknowledged in responses by the United States to commentaries by international bodies (See, for example, Response of the United States to Inquiries of CERD Rapporteur, 2009, Response to paragraph 36).

International law is, however, a highly relevant tool for interpreting law and policy in the United States. The relationship between international law, often called the Law of Nations, and the law of the United States has been recognized in American jurisprudence as far back as 1793 (Henfield's Case, II F. 1099, Cas.C.C.D. Pa., 1793). The Restatement (Third ) of the Foreign Relations Law of the United States claims: "Matters arising under customary international law also arise under 'the laws of the United States' since international law is 'part of our law...'(§102(2))."

International human rights law regarding the right to culture of ethnic, linguistic and indigenous minorities is directly relevant to American educational policy and practice. Indeed, unless American public education embraces the efforts of ethnic, linguistic and indigenous minority communities in the United States to define their educational goals for their children, American public education will continue to fall outside of the global discourse on educational rights of children and their families. Creating a positive environment for these necessary conversations and dialogues to occur, however, requires that global human rights discourse be brought down to the level where decisions on curriculum and assessments are being made - to the school district, the local school and the classroom and to the state departments of education where decisions are made on the content of curriculum and methods of instruction.

\section{Education and the Right to Culture-Some International Human Rights Perspectives}

The Charter of the United Nations calls for respect for the human rights and fundamental freedoms of individuals, including freedom from discrimination (U.N. Charter, Article 1, Section 3). The Universal Declaration of Human Rights recognizes the right of all persons to be free from discrimination, and rights to share in the fruits of the community's life. These include the right to "participate in the cultural life of the community" and the right to education "directed to the full development of the human personality... Parents are recognized as possessing a "prior right to choose the kind of education that shall be given to their children" (UDHR, articles 1, 2 , and 26). Ethnic, religious and linguistic minorities and indigenous peoples are not specifically addressed in the Declaration. However, indigenous and minority parents are clearly beneficiaries of this right to choose an appropriate education. It is reasonable that the leaders of an indigenous society could in many cases assert this right on behalf of the parents among them or that the adults of a minority community could assert it collectively through their representatives.

Thanks to the work of the United Nations Economic and Social Council and its Commission on Human Rights (now the Human Rights Council), the rights identified with generality in the Universal Declaration of Human Rights are given more specific expression in the two covenants adopted by the United Nations General Assembly in 1966. These include the International Covenant on Economic, Social and Cultural Rights (ICESCR) and the International Covenant on Civil and Political Rights (ICCPR). Of the two covenants, the ICCPR provides the greatest support for minorities and indigenous peoples seeking to control the education provided to their children. In addition, the ICCPR has been ratified with the advice and consent of the United States Senate, while the ICESCR has been signed by the United States, a status of approval which provides certain assurances of conformity in principle, but does not have the weight of formal ratification by the Senate.

The International Covenant on Civil and Political Rights provides the first clear assertion of the rights of minorities, including by implication indigenous minorities, to be different, to remain distinct within the culture of the larger nation state. In particular, Article 27 of the ICCPR provides:

In those States in which ethnic, religious or linguistic minorities exist, persons belonging to such minorities shall not be denied the right, in community with the other members of their group, to enjoy their own culture, to profess and practice their own religion or to use their own language. 
Article 27 does not speak specifically of education. However, the relation between education and cultural continuity is so intimate that this right to culture is meaningless beyond the span of a single generation unless it includes a right to an education that nurtures the continuation and development of a minority culture and language (Charleston, 1994).

The United States has also ratified, with the advice and consent of the Senate, the Convention on the Elimination of All Forms of Racial Discrimination. This convention, overseen by the Committee on Racial Discrimination of the U.N. Human Rights Council, includes within its understanding of "racial discrimination," any "distinction, exclusion, restriction or preference based on race, colour, descent, or national or ethnic origin" (CERD, Part I, Article 1, §1).

A more recent iteration of the rights protected by the ICESCR and the ICCPR reflects the growth of international awareness of the need to recognize and protect the collective nature of minority rights. This statement, the Declaration of the Rights of Persons Belonging to National or Ethnic, Religious or Linguistic Minorities was adopted by the U.N. General Assembly in 1992. This Declaration, while not carrying the binding force of an international covenant ratified by the governments of nation states, recognizes the right of "persons belonging to minorities" to "exercise their rights ... individually as well as in community with other members of their group" (Article 3) and to "express their characteristics and to develop their culture, language, religion, traditions and customs"(Art. 4, sec.2).

The growing international recognition of the linkage between control of education and protection of minority cultures and languages and a new international awareness of the special status of Indigenous peoples are reflected in the Convention on the Rights of the Child, adopted by the U.N. General Assembly in 1989. This convention provides, in part:

Article 5. State Parties shall respect the responsibilities, rights and duties of parents, where applicable, the members of the extended family or community as provided for by local custom, legal guardians or other persons legally responsible for the child, to provide, in a manner consistent with the evolving capacities of the child, appropriate direction and guidance in the exercise by the child of the rights recognized in the present Convention (emphasis added).

Article 28 1. States Parties recognize the right of the child to education.

Article 29. 1. State parties agree that the education of the child shall be directed to:

c. The development of respect for the child's parents, his or her own cultural identity, language and values, for the national values of the country in which the child is living; the country from which he or she may originate, and for civilizations different from his or her own (emphasis added).

Article 30. In those States in which ethnic, religious or linguistic minorities or persons of indigenous origin exist, a child belonging to such a minority or who is indigenous shall not be denied the right, in community with other members of his or her group, to enjoy his or her own culture, to profess and practice his or her own religion or to use his or her own language.

Like so many other contemporary human rights agreements, the Covenant on the Rights of the Child is currently signed by the United States but not ratified by the U.S. Senate, thus allying the United States with Somalia as the only two United Nations members who have not ratified the Convention. The present Administration has suggested that it might renew the executive recommendation of the Convention to the Senate for fresh consideration, since the measure has not been rejected by the Senate either. However, at this writing, U.S. ratification of the Covenant on the Rights of the Child appears to languish below the radar.

\section{Interpretations of the Human Right to Culture}

The Covenant on the Rights of the Child reflects a growing international understanding of the link 
between the right to culture and the right to education. This linkage received extensive investigation and analysis in a study commissioned in 1971 by the U.N. Sub-Commission on the Prevention of Discrimination and Protection of Minorities pursuant to the ICCPR. The Sub-Commission appointed Francesco Capotorti as Special Rapporteur to study the implementation of the principles contained in Article 27 of the International Covenant on Civil and Political Rights, the right to culture.

Special rapporteurs "are prominent human rights figures from various walks of life. They include current and former holders of high judicial office, academics, lawyers and economists, former and current members of non-governmental organizations, and former senior staff members" of the United Nations (Fact Sheet \#27, UN Office of High Commissioner for Human Rights, 2001, FAQ \# 6). They serve without salary and are chosen for their particular expertise in an area of human rights concern and their history of commitment to human rights. Special Rapporteurs take testimony and written analyses from both advocates and members of threatened groups as well as from the representatives of the various nation states. They conduct their own research, both in the field and in research libraries. They consult with experts in all relevant fields such as law, education, anthropology, political science, economics, environmental science and development analysis, to name a few. They then report to the High Commissioner on Human Rights, to the working group or sub-commission which has commissioned them and to the world community.

As a Special Rapporteur investigating the implications of the right to culture for ethnic, religious and linguistic minorities, Capotorti conducted a comprehensive, multi-year investigation of policies and practices of nation states which impact the cultural development and cultural survival of minority groups (Capotorti, 1979). Together with many other policy areas, he reviewed extensively the impact of educational policies, practices and resource allocations on minority groups. In his final report, written in 1977 and disseminated by the United Nations in 1979, Capotorti concluded:

There can be no possible development of the culture of any group if members of that group are denied the right to education or are treated in a discriminatory manner. Educational policy is therefore a key element in evaluating the situation of persons belonging to minority groups as regards their right to enjoy their own culture (Capotorti, 1979, paragraph 341).

Capotorti insisted that:

[A]ssimilation is a process which should in no case be imposed on members of minority groups.... As the preservation of the cultural identity of the minority group is of particular importance to their survival, not only should their right to development of their own culture be recognized in constitutions and in laws, but specific actions should be taken concerning the implementation of this right. (paragraphs 589, 592)

Capotorti paid particular attention to the role of the minority language in maintaining the cultural distinctness of the group and the importance of the minority language in the education of minority children:

The use of the language of minority groups in the educational system is a crucial test for determining the ability of these groups to maintain and develop their own characteristics. Language being an essential element of culture, the capacity of a minority group to survive as a cultural group is in jeopardy if no instruction is given in its language (paragraph 604).

In addition to being assured of education in its own language, the children of a minority group must also be given the opportunity for instruction in the national language, he noted (paragraph 606).

\section{Education and the Human Right to Culture -- the Special Case of Indigenous Peoples}

In 1971, the Economic and Social Council authorized the U.N. Sub-Commission on Prevention of Discrimination and Protection of Minorities to 
conduct a study on the "Problem of Discrimination against Indigenous Populations". The Sub-commission recognized the growing threat, worldwide, to the survival of indigenous peoples as distinct cultures and the precarious situation of many of the world's remaining indigenous communities. The Subcommission's charge resulted in a five-volume study by Special Rapporteur Jose Martinez Cobo issued over the period from 1981 to 1983 and published by the United Nations for dissemination in 1987.

The Martinez Cobo study has led to the development of international documents, including declarations and protocols dealing specifically with the rights of indigenous peoples (ILO Convention 169 1989; Declaration of the Rights of Indigenous Peoples, adopted by the U.N. General Assembly in September, 2007). However, like the study by Capotorti, Martinez Cobo's report and its conclusions are grounded in the international human rights precedents existing at the time it was written (Martinez Cobo, 1987). Thus, the study considered what was required of nation states to conform to existing international human rights standards in their dealings with their resident indigenous peoples and examined the extent to which nation states with indigenous population groups deviate from those existing standards.

Martinez Cobo addressed both the need to develop and support the use of indigenous languages and the stereotypes about language which often caused nation states to resist indigenous language development:

Public schooling oriented toward doing away with indigenous characteristics and the policies of marginalization, relegation and elimination of indigenous languages followed by most States, many of which inherited them from the colonial period, have been questioned and utterly rejected. There is increasing acceptance of the need to recognize, once and for all, the pluralingual and pluracultural nature of the countries where indigenous populations live and to adopt unequivocally policies which permit and promote the conservation, development and dissemination of the specific ethnic nature of those populations and its transmission to future generations (paragraph 123).

The Martinez Cobo Study included extensive recommendations for the establishment of schools in indigenous communities, for the use of the Indigenous language in the instructional programs of indigenous schools, for the development, with the indigenous community, of culturally appropriate curricular materials for use in the schools, for preparation and recruitment of teachers from among the Indigenous community itself and for indigenous control of indigenous education. In sum, Martinez Cobo concluded that the right to culture guaranteed by the ICCPR requires nation states with indigenous populations to act affirmatively in concert with such peoples to develop educational systems, programs and practices which support and foster their linguistic and cultural continuity. These recommendations are as relevant today as they were when the study was first published.

The right to culture of indigenous peoples was given confirmation by the General Assembly of the United Nations through its adoption of the Declaration of the Rights of Indigenous Peoples in September of 2007. The United States did not vote for the declaration, although President Obama has announced, in a change of position from the previous administration, official United States support for the Declaration (Obama, 2010). General Assembly declarations do not carry the force of treaties ratified by the governments of state parties. Nonetheless, the overwhelming size of the majority of nations favoring the Declaration, now including the United States, together with the extensive scholarly research, international discussion and debate that accompanied its development and adoption have incorporated the Declaration into those "widely shared and intensely demanded values "(Chen, 2000, p.199) which rise to the status of a "Global bill of human rights" (Chen, p. 78). Indeed, the interpretations given to the existing body of Human Rights treaties and declarations in regard to the education of Indigenous Peoples under existing international law standards confirm Martinez Cobo's conclusions (Expert Mechanism on Rights of Indigenous Peoples, Report on Education, August, 2009). 


\section{Contemporary Expression of the Relationship between the Right to Education and the Right to Culture}

More recently the United Nations Economic and Social Council (UNESCO) has appointed a special rapporteur to investigate the status of the right to education in the various nation states and regions. Vernor Muñoz Villalobos, in a report published in December of 2004, concluded that education must be recognized as a human right, and as such it must be made both available and inclusive. His report concluded:

70. Diversity is a cornerstone of education. It manifests itself in intercultural community life and respect for the differences between people. The Special Rapporteur thus conceives of development as a collective learning process that people must undergo to realize that democratization and anti-discrimination are essential to a dignified life.

71. Given that one of the aims of education is to instill respect for civilizations different from that of the student, the Special Rapporteur believes that a discussion of intercultural relations should be an automatic feature of all education systems.

72. Homogeneity in education is an impossible undertaking. Pressure to entrench the use of one language for all peoples, for example, is a sign of intolerance...

Of course Mr. Villalobos was addressing education from a universal perspective. His conclusions have been reinforced, with even greater clarity by those individuals, organizational representatives and international bodies which particularly address the needs of racial, ethnic, linguistic minorities and indigenous peoples. The UN Special Expert on the Minority Issues summed up the relationship between the right to education consistent with national standards and priorities and education to support the unique needs and identities of minority communities as follows:
5. In the context of rights and obligations recognized at the level of the United Nations and regionally, education should serve the dual function of supporting the efforts of communities to self-development in economic, social and cultural terms while opening pathways by which they can function in the wider society and promote social harmony (Addendum to Report of UN Forum on Minority Forum by Gay McDougall, December, 2008).

Likewise, the UN Human Rights Council's Expert Mechanism on the Rights of Indigenous Peoples concluded:

5. Education is recognized as both a human right in itself and an indispensable means of realizing other human rights and fundamental freedoms, the primary vehicle by which economically and socially marginalized peoples can lift themselves out of poverty and obtain the means to participate fully in their communities. Education is increasingly recognized as one of the best long-term financial investments that States can make (Expert Mechanism Report on Education, August, 2009).

This paper has paid a considerable amount of attention to the conventions, declarations and studied opinions of international organizations (which are reinforced and often surpassed in the declarations of regional organizations around the globe) because it is so important for American educators and education policy makers to have some basis for putting American attitudes, and even American laws impacting education of ethnic, linguistic and indigenous minorities, into an appropriate global context. The United States does not exist in a vacuum. American practice is not detached from the law of nations. The jurists who established the American system of laws and interpreted the United States Constitution from its ratification and earliest days of interpretation have always recognized their umbilical connection to the law of nations and the opinion of 
humankind. The obligation to protect and strengthen the linguistic and cultural identity of minority students is almost universally recognized throughout the world. There is a problem if the educational laws and policies of the American nation, which historically has played such an important role in bringing human rights standards to the world stage, do not support and strengthen ethnic and linguistic diversity.

\section{Implementing the Right to Culture in United States Education}

Despite institutional reluctance to formally acknowledge the place of international human rights law in the practices and policies of the United States, there are countervailing traditions in American law that hold the fruit of worldwide legal consensus, developed over time, as part of the rule of law to which the United States is committed. The norms expressed through the various international charters, covenants, conventions and declarations, viewed collectively, express the "opinions of mankind" for which Thomas Jefferson once declared Americans should have a "decent respect" (Declaration of Independence, paragraph 1; see commentary by Blackmun, 1994). As such, they form a body of customary international law. The phrase "customary international law" is a contemporary phrase for the "Law of Nations" upon which the whole development of international law rests (Anaya, 1996; Hartman, 1985). Chen (2000), in his iconic treatise on international law, stated:

The technical requirements of establishing a customary international law are commonly said to be two: a "material" element in certain past uniformities in behavior and a "psychological" element, or opinio juris, certain subjectivities of legal 'oughtness" attending the uniformities in behavior... ( $p$. 344)

Under contemporary theories of international law, when a controlling consensus exists among the nation states and the world's people about a minimum standard that should govern behavior toward a particular group, such as national, ethnic and linguistic minorities and Indigenous peoples, based upon widely shared values regarding human dignity, that consensus constitutes customary international law. It is interesting to note that these contemporary interpretations of the relationship between national jurisprudence and international law represent a full circle back to the law of nations upheld by John Jay, the first Chief Justice of the U.S. Supreme Court, in Henfield's Case (1793, supra) in the earliest years of the republic. In this early decision, Henfield was held to be criminally liable in American courts for privately engaging in predations upon nations with whom the United States was at peace.

The court advised the jury, "This is the law of nations; ... a law that was in existence long before Gideon Henfield existed." The principle that the law of nations is a part of the law of the United States has been reaffirmed by American courts throughout the long history of the republic. One clear expressions of the place of international customary law in American practice was a straightforward statement by the U.S. Supreme Court in the very first days of the 20th Century, that "International law is part of our law..."(Paquete Habana, 1900, p. 700). In seeking interpretations of that law, the Court noted that a reliable resource exists in "the works of jurists and commentators who by years of labor, research, and experience have made themselves peculiarly well acquainted with the subjects of which they treat" (p. 700). Quoting a prominent contemporary treatise on international law, the court observed regarding these jurists and commentators:

They are witnesses of the sentiments and usages of civilized nations, and the weight of their testimony increases every time that their authority is invoked by statesmen, and every year that passes without the rules laid down in their works being impugned by the avowal of contrary principles. (p. 701, quoting Wheaton, 8th ed., p. 15)

Thus, recognition in the conventions and declarations of international and regional organizations that ethnic, linguistic and indigenous minority communities have the right to expect public schools to protect and support their children's cultural and linguistic identity creates overwhelming evidence of a 
customary human right to culturally and linguistically appropriate education. Likewise, the analyses of international human rights jurists provide that body of learned opinion upon which this right comfortably rests.

In its ratification of the International Covenant on Civil and Political Rights, the U.S. Senate explained one of its reservations against direct Federal enforcement of the covenant as follows:

That the United States understands that this Covenant shall be implemented by the Federal Government to the extent that it exercises legislative and judicial jurisdiction over the matters covered therein, and otherwise by the state and local governments; to the extent that state and local governments exercise jurisdiction over such matters, the Federal government shall take measures appropriate to the Federal system to the end that the competent authorities of the state or local government may take appropriate measures for the fulfillment of the Covenant. (U.S. Senate, 1992, S 4783)

The Senate language makes it clear that state and local governments have the responsibility for the execution of the International Covenant in the performance of their governmental functions and duties. State education laws and regulations and local education ordinances and policies must protect the right to culture of ethnic, linguistic and religious minorities and Indigenous peoples as fully as Federal laws. The interpretations of Article 27 by special rapporteurs Capotorti and Martinez Cobo and the interpretations of the international law criteria for treatment of Indigenous peoples (and of national, ethnic, linguistic and religious minorities generally) by other nation states are principles which should guide state and local education decisions in the United States as well. Programs operated under any legal authority in which public dollars are expended for education or in which public law and policy is made affecting public or private education should be considered subject to the U.S. Senate's assurance that "the Federal government shall take measures appropriate to the Federal system to the end that the competent authorities of the state or local government may take appropriate measures for the fulfillment of the Covenant."

It is certainly true that discussion of the implications of the International Covenant on Civil and Political Rights has been largely absent from the rooms where state and local laws and policies are created. However, it is also true that members of the affected public have been uninformed and may not realize that the good that they desire is also a right which they deserve. The challenge for members and allies of minority ethnic, linguistic and indigenous communities is to bring about a change in the way multicultural education is discussed in American schools and in the centers of power where education laws, regulations and policies are made and interpreted.

\section{Conclusion}

Members of racial, ethnic, linguistic and indigenous minorities share a fundamental right with all people to look to the institutions of public education to help them form the next generation who will carry on their identity and their way of life. If they speak a language other than the common national language, they have a fundamental right to look to the institutions of public education to help them maintain that language through coming generations. At several points in its history, the United States has affirmed its commitment to these fundamental rights in open and public declarations. A representative of the United States, Eleanor Roosevelt, chaired the committee of the United Nations that drafted the Universal Declaration of Human Rights. The United States representative to the General Assembly proceedings voted for the Declaration. The United States President signed and the Senate ratified the International Covenant on Civil and Political Rights and the Convention on the Elimination of All Forms of Racial Discrimination. The United States, belatedly, has declared its approval of the Declaration on the Rights of Indigenous Peoples.

These commitments present a challenge both to mainstream education policymakers and to advocates for multicultural, bilingual or multilingual education. When mainstream policymakers and advocates for the right to culture communicate based on a shared understanding of the mismatch between the U.S. 
international stance and its national policies, people of good will and great skill can determine what effective education can mean in this pluralistic democracy. The failure of this country to live up to its commitment to the right to culture has undermined the education of racial, ethnic, linguistic and indigenous minority students throughout the history of American public education. It has also diminished the quality of education for all. Many of those countries whose test scores Americans envy incorporate multilingualism into their core educational expectations and give specific recognition to the rights of their ethnic and linguistic minorities in their education laws (See, for example, the European charter for regional or minority languages, entered into force, 1998).

When American children from racial, ethnic, linguistic and indigenous minorities and diverse cultural communities reach for the highest levels of educational attainment as they have both the right and the ability to do, they also have the right to arrive there whole. It is the responsibility of those privileged to teach them to help them to weave all that they are, all that their families and their people are culturally, historically and linguistically, into the holistic fabric of what they are becoming. The language of educational reform needs to incorporate the language of human rights. The United States has given its solemn promise to nurture the diverse cultures of its people. It is only with the support of the public schools that this promise can be realized for longer than a single generation.

\section{REFERENCES}

American Law Institute (1988-2009). Restatement (Third) of the foreign relations law of the United States. Philadelphia, PA: American Law Institute. Eagan, MN: West-Thompson.

Anaya, J. (1996). Indigenous people in international law. New York, Oxford: Oxford University Press.

Blackmun, H. (1994). The Supreme Court and the law of nations. Yale Law Journal, 104, 39-40.

Bloom, A. (1987). The closing of the American mind. New York: Simon Schuster.

Capotorti, F. (1979). Study of the rights of persons belonging to ethnic, religious and linguistic minorities. New York, NY: United Nations.

Chaiklin, S. and Lave, J. (1993). Understanding Practice Perspectives on activity and context. Cambridge, UK: Cambridge University Press.

Charleston, G. M. (1994) Toward true native education, a Treaty of 1992 - Final report of the Indian nations at risk taskforce, craft 3. Journal of American Indian Education, 33 (2), 10-56.

Chen, L.C. (2000). An introduction to contemporaryinternational law. New Haven, CT: Yale University Press.

Cheney, L. (1995). Telling the truth: Why our culture and our country have stopped making sense - And what we can do about it. New York: Simon Schuster.

Council of Europe (1998). European charter for Regional or Minority Languages. Council on Europe Treaty Service No. 148. Retrieved September 4, 2009 from http:// conventions.coe.int/treaty/Commun/QueVoulezVous. asp?NT=148\&CL=ENG .

Fuhrman, S. (1994). Challenges in systemic education reform. New Brunswick, NJ: Consortium for Policy Research in Education. (ERIC Document Reproduction Service No. ED377562)

Fuhrman, S., Clune, W. \& Elmore, R. (1988). Research on education reform: Lessons on the implementation of policy. In Allan R. Odden (ed.), Education policy implementation (pp. 197-218). New York, NY: State University of New York Press.

Gagne, E., Yekovich, C.W., \& Yekovich, F. (1995). The cognitive psychology of school learning (2nd ed.). Boston: Allyn and Bacon.

Hartman, J. (1985). Enforcement of international human rights law. Whittier Law Review, 7, 741.

Henfield's Case (1793): 11 F. Cas 1099 (C.C.D. Pa.), Jay, C.J.).

Hirsch, E.D. (1987). Cultural literacy: What every American needs to know. Boston: Houghton Mifflin.

Martinez Cobo, J. R. (1987). Study of the problem of discrimination against indigenous populations-volume V: Conclusions, proposals and recommendations. New York: United Nations.

New Mexico Public Education Department (2007). Working together: School, family and community partnerships, a toolkit for New Mexico school communities. Retrieved September 4, 2009, from http://www.ped.state.nm.us/ div/rural_ed/index.html and http://www.cesdp.nmhu. edu/toolkit/index.html 
Obama, Barack. (2010). Remarks by the President at the White House tribal nations conference. Washington, DC: Office of the Press Secretary, White House. Retrieved December 16, 2010, from http://www.whitehouse.gov/the-pressoffice/2010/12/16/remarks-president-white-housetribal-nations-conference.

Shapiro, J.P., Sewell, T. \& DuCette J. (1992). Toward a resolution of a paradox between diversity and accountability for school administrators: Application of the principles of feminist assessment. (ERIC Document Reproduction Service No. ED355654)

Sleeter, C. (1995). An analysis of the critiques of multicultural education. In Handbook of research on Multicultural Education (pp. 81-94). San Francisco, CA: Jossey-Bass.

Villalobos, Verner Muñoz. (2005). Economic, social and cultural rights: The right to education. (United Nations report E/ CN.4/2005/50). New York: United Nations.

United Nations Committee on the Elimination of Racial Discrimination (CERD). (2010). Consideration of reports submitted by States parties under article 9 of the Convention : concluding observations of the Committee on the Elimination of Racial Discrimination. (Report No. CERD/C/ISL/CO/19-20). New York: United Nations.

United Nations Committee on the Elimination of Racial Discrimination (CERD). (2008). Questions put by the rapporteur in connection with the combined fourth, fifth and sixth periodic reports of the United States of America. (Report No. CERD/C/USA/6). New York: United Nations.

United Nations Human Rights Council (2009). Expert mechanism on rights of indigenous peoples: Study on lessons learned and challenges to achieve the rights of indigenous peoples to education. (Report No. A/ HRC/12/33). New York: United Nations.

McDougall, G. (2009). Promotion and protection of all human rights, civil, economic, social and cultural rights, including the right to development. (Report No. A/HRC/10/11/ Add.1). New York: United Nations.

Mohácsi, V. (2009). Summary by the chairperson of the forum on minority issues. (Report No. A/HRC/10/CRP.2). New York: United Nations.

United Nations Committee on the Elimination of Racial Discrimination (CERD). (2009). United States response to specific recommendations identified by the Committee on the Elimination of Racial Discrimination. New York: United Nations.

United States Department of State: Bureau of Democracy, Human Rights \& Labor. (2009). Description of Bureau and portal to site. Retrieved on September 9, 2009, from http://www.state.gov/g/drl/index.htm

The Paquete Habana. 175 U.S. 677.

Parents Involved in Community Schools v. Seattle School District No. 1. 551 U.S. 701 (2007).

Wheaton, H, \& Dana, R.H. (1886, 1991 facsimile). Elements of International Law (8th ed.). New York: L.B. Adams, Jr.

Yell, M. L., \& Drasgow, E. (2004). No Child Left Behind: A Guide for Professionals. Old Tappan, New Jersey: Pearson/Allyn Bacon/Merrill. 